\title{
無電解Snめっき膜より発生したウィスカの形態
}

\author{
岡本 尚樹*, 藤井 祐子 ${ }^{*}$, 栗原 宏明 ${ }^{* *}$, 近藤 和夫 ${ }^{*}$
}

\section{The Morphologies of the Sn Whiskers Formed in the Sn Electrolessdeposited Film}

\author{
Naoki OKAMOTO*, Yuko FUJII*, Hiroaki KURIHARA** and Kazuo KONDO*
}

\footnotetext{
*大阪府立大学大学院工学研究科化学工学分野 (广599-8531 大阪府堺市中区学園町 1-1)

**三井金属鉱業株式会社マイクロサーキット事業部製品開発部（テ750-0093 山口県卜関市彦島业山町1-1-1 株式会社エム・シー・エス内）

* Department of Chemical Engineering, Graduate School of Engineering, Osaka Prefecture University (1-1 Gakuen-cho, Naka-ku, Sakai-shi, Osaka 599-8531)

**New Product Development Department, Micro Circuits Division, Mitsui Mining and Smelting Co., Ltd. (MCS, Inc., 1-1-1 Hikoshima Nishiyamacho, Shimonoseki-shi, Yamaguchi 750-0093)
}

概要 本研究ではほとんど研究報告がない無電解Snめっき膜より発生するウィスカについて, 特に, 基板の笔解釦箔の結 晶粒径の違いによるウィスカの発生数および構造の違いについて注月して検討を行った。これに加えて，ウィスカ発生を抑制 するナ法とそのメカ二ズムについても検討を行った。われわれは，特に基板の結唱粒径の人きさと形成される金属閭化合物の

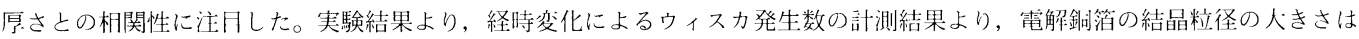
金属閒化合物の形成とウィスカ発生数に影響を与えることがわかった。またそれは，䉓解銅䇴の結唱粒径が小さくなることに よって，より厚い金属䦎化合物が形成され，それによりウィスカの発生数が増加することを示している。

\begin{abstract}
In this study, the structures of electroless deposited tin films and tin whiskers that formed on the films were investigated. In addition, we focused on how to retard the growth of the whiskers and investigated these mechanisms. In particular, we considered the relationship between the crystal grain size of $\mathrm{Cu}$ foils and the thickness of the IMC layer. From our results, we can see that the grain size of the substrate has an impact on IMC growth and whisker formation. These results also show that a smaller grain size results in a thicker IMC layer and the formation of more tin whiskers.
\end{abstract}

Key Words: Whisker, Sn, Electroless Deposition, Cu Foil, Structure

\section{1. 緒 言}

EU（欧州連合）の RoHS 指令による電気・電子機器にお ける有害物質の規制が 2006 年 7 月 1 日から施行された。そ れに伴い, $\mathrm{Pb}$ を含有しない $\mathrm{Pb}$ フリーはんだの利用が進め られている。現在，第一世代 $\mathrm{Pb}$ フリーはんだとして $\mathrm{Sn}-\mathrm{Ag}$, $\mathrm{Sn}-\mathrm{Bi}, \mathrm{Sn}-\mathrm{Cu}$ などの合金めっきが実用化されている1)。し かし，これらの合金めっきはいずれも浴管理が難しい。ま た， $\mathrm{Pb}$ フリー化によって，Sn系合金はんだめっきでは， ウィスカが発生し, 回路の短絡などを引き起こす問題が指

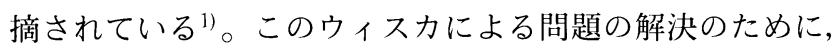
電子部品の表面処理では Auめっきを施す方法により解決 がなされているが, Snに比べてコストが高く, 環境負荷も 大きい。そのため, ウィスカ抑制が可能であれば $\mathrm{Sn}$ 系めっ きを用いることが望ましいと考えられる。また, 第二世代 の $\mathrm{Pb}$ フリーはんだとして純 $\mathrm{Sn}$ めっが注目されている11。

ウィスカ発生メカニズムについてはこれまでにさまざま な研究がなされている2),3)。その中で, ウィスカの発生原因 については, 結晶の歪や金属間化合物層の形成によって Sn めっき膜中に生じる内部応力が主な原因であると指摘され
ている。ウィスカの発生機構の考察は, さまざまな電析 $\mathrm{Sn}$ 合金めっきの系で検討されている。しかし, 無電解 Snめっ き膜より発生するウィスカについての研究報告は少ない。

そこで, 本研究では基板となる電解銅箔の結晶粒径の違 いに注目し，電解銅䇴上の無電解 Snめっき膜から発生す るSnウィスカの形態とその経時変化を検討した。

\section{2. 実験方法}

基板には 2 種類の電解銅箔を用いた。電解銅箔の作製は, 陽極に銅板，陰極にはチタン板を用い，定電流電解により 電流密度 $125 \mathrm{~A} / \mathrm{m}^{2}$ で浴を攪抖して行った。電解浴には, 基 本組成を $240 \mathrm{~g} / \mathrm{dm}^{3} \mathrm{CuSO}_{4} \cdot 5 \mathrm{H}_{2} \mathrm{O}$ および $100 \mathrm{~g} / \mathrm{dm}^{3} \mathrm{H}_{2} \mathrm{SO}_{4}$ とし て，ゼラチン $50 \mathrm{mg} / \mathrm{dm}^{3}$ を添加した浴（以下，この浴を用 いて作製した銅箔をゼラチン添加と表記）と， $\mathrm{Cl}^{-}$イオン $50 \mathrm{mg} / \mathrm{dm}^{3}$ を添加した浴（以下，同様に $\mathrm{Cl}^{-}$添加と表記） の 2 種類を用いた。これまでの研究で, 電解銅箔の結晶粒 の大きさや結晶配向性が, ゼラチン添加と $\mathrm{Cl}^{-}$添加との違 いにより変化することがわかっていることから ${ }^{4)}$ ，それら を基板（膜厚 $25 \pm 2 \mu \mathrm{m}$ ） として用いた。作製した電解銅箔 に市販浴を用いて約 $0.6 \mu \mathrm{m}$ の無電解 $\mathrm{Sn}$ めっき膜を施した。 
作製したSnめっき膜を室温・大父環境下でプラスチック ケースに入れて 30 日間保管し，その間に発生したウィスカ の数および形態を観察した。ウィスカの分布状態を光学顕 微鏡（オリンパス製BX60M）とFE-SEM（日立製作所製， S-4300）により観察した。電解銅箔，めっき膜およびウィ スカの断面形態をTEM（日立製作所 HD-2000 および日本電 子JEM-2010F）により観察し，同時にEDS（ノーラン社製, UTW 型 Si(Li) 半導体検出器) により組成の分析を行った。 また，結晶配向性をX 線回折装置（リガク製，RINT-1500） により解析した。Snめっき膜の膜厚は蛍光 X 線分析装置 （セイコーインスツルメンツ社製, SFT-9300）を用いて测 定した。

\section{3. 実験結果および考察}

\section{1 電解銅箔と Snめっき膜の結晶粒径および 結晶配向性}

作製した電解銅馢断面の明視野像をFig. 1 にホす。(a)は
ゼラチン添加, (b) は $\mathrm{Cl}^{-}$添加の電解銅䈃である。(a)の結晶 粒は粒状で，その粒径は約 $0.3 \mu \mathrm{m}$ であった。一方，(b)の結 晶粒は柱状で, その平均径は約 $5 \mu \mathrm{m}$ であった。同様に, 電 解銅箔上に作製した無電解 Snめっき膜の結晶粒径は, ゼ ラチン添加では約 $0.03 \mu \mathrm{m}, \mathrm{Cl}^{-}$添加では約 $4.1 \mu \mathrm{m}$ で, $\mathrm{Cl}$ 添加の方がゼラチン添加よりも大きくなっていた。それぞ れの電解銅箔の結晶粒径の大きさに応じて, Snめっき膜の 結晶粒径が異なることを確認した。また，電解銅箔および 無電解Snめっき膜之もに結晶粒径の経時変化は観察され なかった。

次に，それぞれの電解銅箔上に作製した無電解 Snめっ き膜の作製後 0 日後, 15 日後, 30 日後の X線回折測定結果 をFig. 2 に示す。0日後 (作製直後) では, 電解銅箔と Sn めっき膜に由来する $\mathrm{Cu}$ と $\mathrm{S}$ に起因するピークが観察され た。また， $2 \theta=30,53,71,79^{\circ}$ 付近にもそれぞれ $\mathrm{Cu}_{6} \mathrm{Sn}_{5}(202)$, (402), (404), (600)のピークがそれぞれ見られる。電解銅箔の 結晶配向性はそれぞれ(a)ゼラチン添加では無配向, (b) $\mathrm{Cl}^{-}$
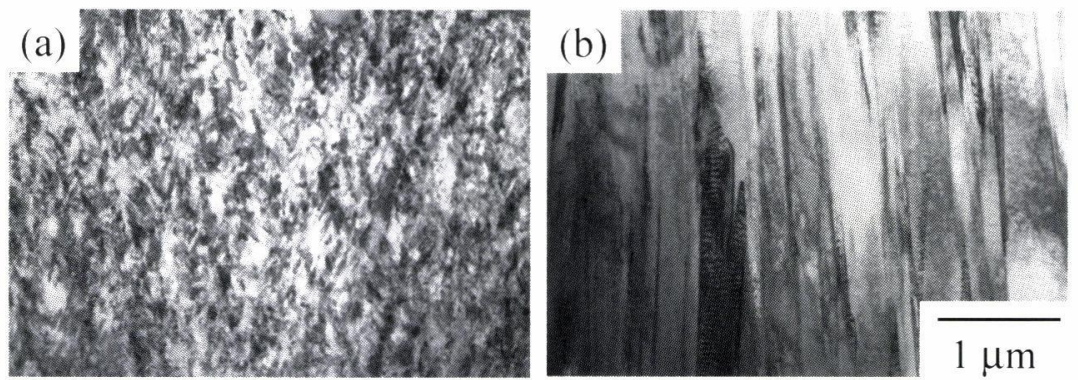

Fig. 1 Cross sectional TEM bright field images of $\mathrm{Cu}$ foil. (a) gelatin, (b) $\mathrm{Cl}^{-}$

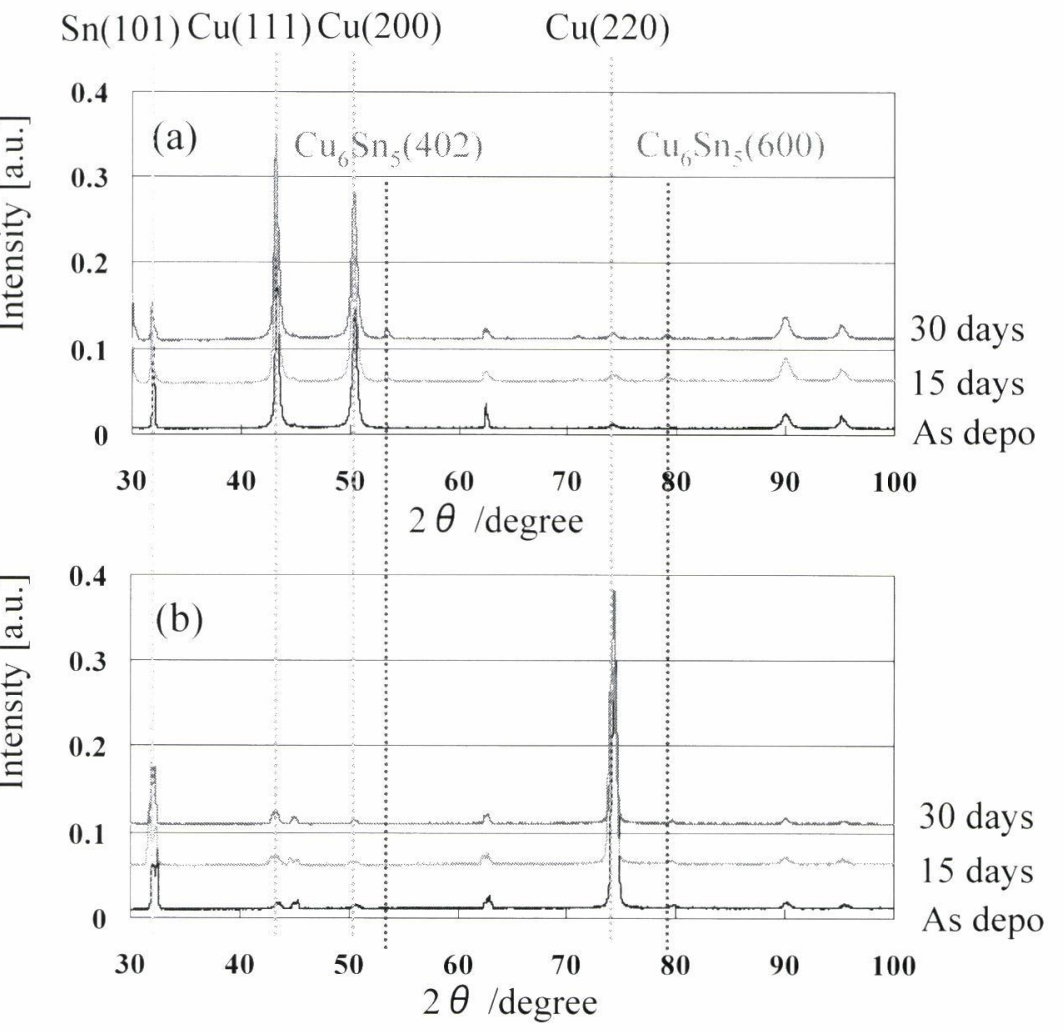

Fig. 2 X-ray diffraction patterns of Sn deposited film and $\mathrm{Cu}$ foil. (a) gelatin, (b) $\mathrm{Cl}^{-}$ 

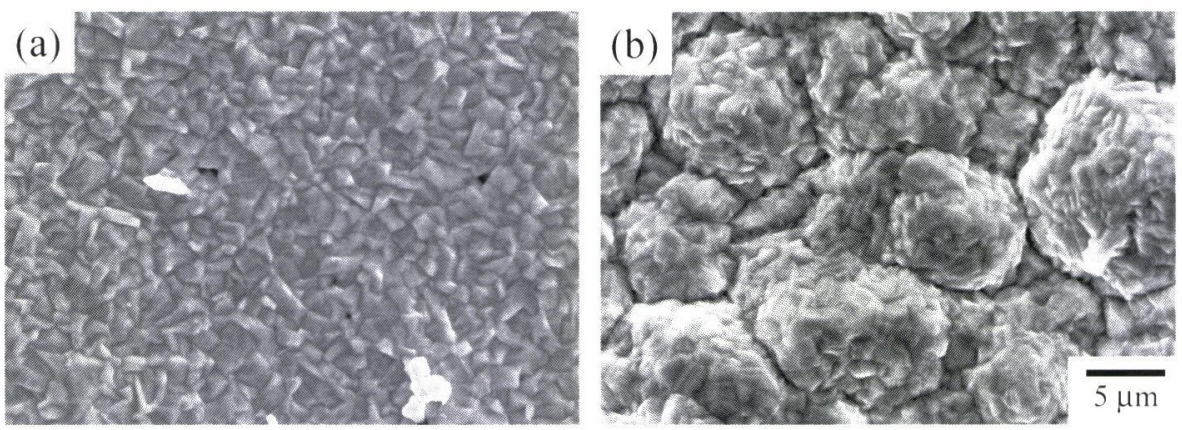

Fig. 3 Surface morphologies of Sn deposited film. (a) gelatin, (b) $\mathrm{Cl}^{-}$

添加では(220)に強く配向していた。Snめっき膜の結唱配 向性は, (a)ゼラチン添加，(b) $\mathrm{Cl}^{-}$添加ともに(112) ピークが やや高くなっているが，基本的に無配向であった。15日 後, 30 日後の XRD パターンについて, (a) ゼラチン添加で は, 15 日後, 30 日後之もに $2 \theta=30,53,71,79^{\circ}$ 付近に見られ る $\mathrm{Cu}_{6} \mathrm{Sn}_{5}(202),(402),(404),(600)$ のピークが0日後に比べて, ピーク強度が大きくなっている。一方, (b) $\mathrm{Cl}^{-}$添加では, 15 月後では $\mathrm{Cu}_{6} \mathrm{Sn}_{5}$ のピークは見られない。30日後では, $2 \theta=79^{\circ}$ 付近に $\mathrm{Cu}_{6} \mathrm{Sn}_{5}(600)$ のピークが見られるが，そのピー ク強度はゼラチン添加の強度に比べて低い。

以上の結果より, ゼラチン添加, $\mathrm{Cl}^{-}$添加のいずれの試 料においても，金属間化合物 $\mathrm{Cu}_{6} \mathrm{Sn}_{5}$ が経時的に形成される ことが示唆された。しかし, ゼラチン添加に比べて $\mathrm{Cl}^{-}$添 加では, 経時変化による $\mathrm{Cu}_{6} \mathrm{Sn}_{5}$ の形成が起こりにくいと考 えられる。また，電解銅簿およびSnめっき膜の結晶配向 性については，明確な倾向が見られないことがわかった。

\section{2 ウィスカの分布}

Fig. 3 にSnめっき膜作製後 $24 \mathrm{~h}$ のときのめっき膜の表面 形態を示す。(a)ゼラチン添加に比べて(b) $\mathrm{Cl}^{-}$添加において 表面形態が粗くなっていることがわかる。(b) $\mathrm{Cl}^{-}$添加では, Fig. 1(b)で観察された電解銅箔の柱状結晶の結晶粒界に沼 うように玔凸が形成されていることがわかる。(a)ゼラチン 添加では, そのような形態は観察されないことから, 電解 銅漩の結唱粒の形態が, Snめっき膜の表面形態に反映され ていることがわかる。

次に, Snめっきののち, 時間の経過に対して発牛した ウィスカの数の変化をFig. 4 に示す。

ウィスカ発生数は, 3 点の計測筒所をあらかじめ選び, それぞれの計測筒所で, 光学顕微鏡で直径 $12.5 \mathrm{~mm}^{2}$ の面積 を観察し内で突起と観察されるものをウィスカとしてカウ ントし，計測した 3 点の平均值をウィスカの個数とした。 ウィスカ発生数は 10 日月まで，ゼラチン添加と $\mathrm{Cl}^{-}$添加は ともに 50 個 $/ \mathrm{cm}^{2}$ であった。15日目以降ゼラチン添加での ウィスカ発牛が大きく增加していた。30日後のウィスカ発 生数はゼラチン添加が約 550 個 $/ \mathrm{cm}^{2}, \mathrm{Cl}^{-}$添加が約 180 倜 $1 \mathrm{~cm}^{2}$ となった。このことから経時変化に伴うウィスカ発生 数が異なることがわかった。

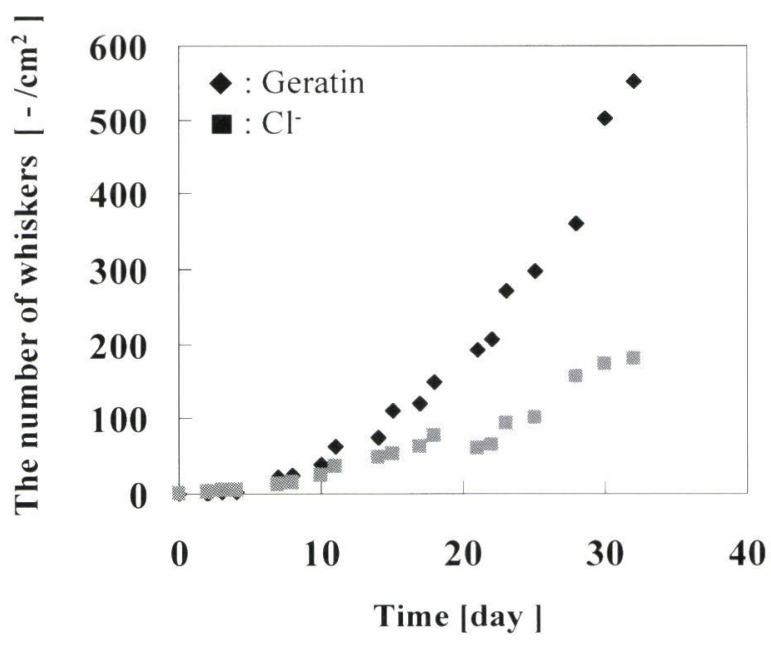

Fig. 4 The number of whiskers that observed on Sn deposited film after an aging

\section{3 ウィスカの経時変化}

ゼラチン添加および $\mathrm{Cl}^{-}$添加の電解銅簿上に作製した $\mathrm{Sn}$ めっき膜の断面形態の経時変化をFig. 5 に示す。いずれに おいても, Snおよび Cuとは異なる層が, Sn めっき膜と電 解銅簿之の間に観察された。X線回折測定の結果之電子線 回折网形による解析を行った結果, それらは, 金属間化合 物 $\mathrm{Cu}_{6} \mathrm{Sn}_{5}$ であることがわかった。それらは, Sn めっき膜之 電解銅䈃との間に層状に形成されていた。その金属間化合 物 $\mathrm{Cu}_{6} \mathrm{Sn}_{5}$ 層の厚さは, ゼラチン添加では, (a) 0 日目は $30 \mathrm{~nm}$, (b) 15 日日は $240 \mathrm{~nm}$, (c) $30 \mathrm{H}$ 月は $560 \mathrm{~nm}$ 之経月的 に明確に増加していた。一方, $\mathrm{Cl}^{-}$添加では, (d) 0 日目は 不連続な層として部分的に観察され，(e) 15 日月は $120 \mathrm{nm,}$ (f) 30 日目は $180 \mathrm{~nm}$ の厚さであった。

作製後 30 日日の無電解 $S n$ めきと電解銅簿との界面近 傍の暗視野像を Fig. 6 に示す。特に(a)ゼラチン添加におい て, Snめっき膜之電解銅䈃之の界面近傍で粒状にコントラ ストのない部分が見られる。そのことから、この部分には ボイドが形成されていると考えられる。(a)ゼラチン添加で はSnめっき膜と電解銅䇴との界面付近に大きさ約 $200 \mathrm{~nm}$ のボイドが多数見られる (aの矢印部分)。一方 (b) $\mathrm{Cl}^{-}$添加 ではボイドはほとんど確認できなかった。このボイドの数 

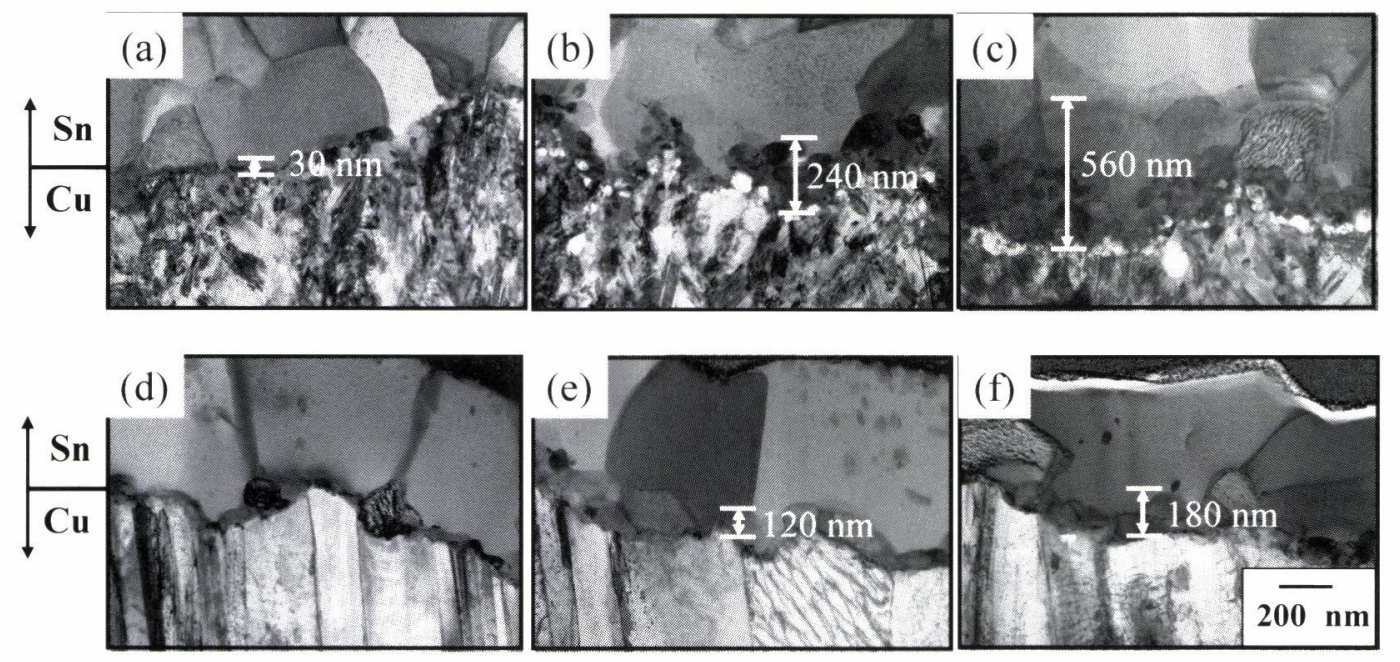

Fig. 5 Cross sectional TEM bright-field images of $\mathrm{Cu}-\mathrm{Sn}$ intermetallic compound layer. (a), (b), (c) gelatin, (d), (e), (f) $\mathrm{Cl}^{-}$(a), (d) as deposition, (b), (e) after 15 days aging, (c), (f) after 30 days aging

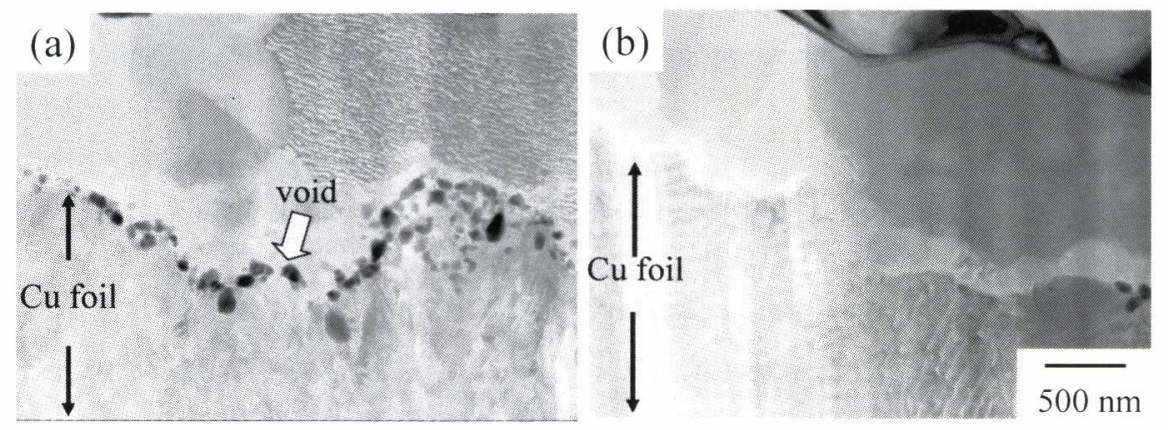

Fig. 6 Cross sectional TEM dark-field images of $\mathrm{Cu}-\mathrm{Sn}$ intermetallic compound layer. (a) gelatin, (b) $\mathrm{Cl}^{-}$
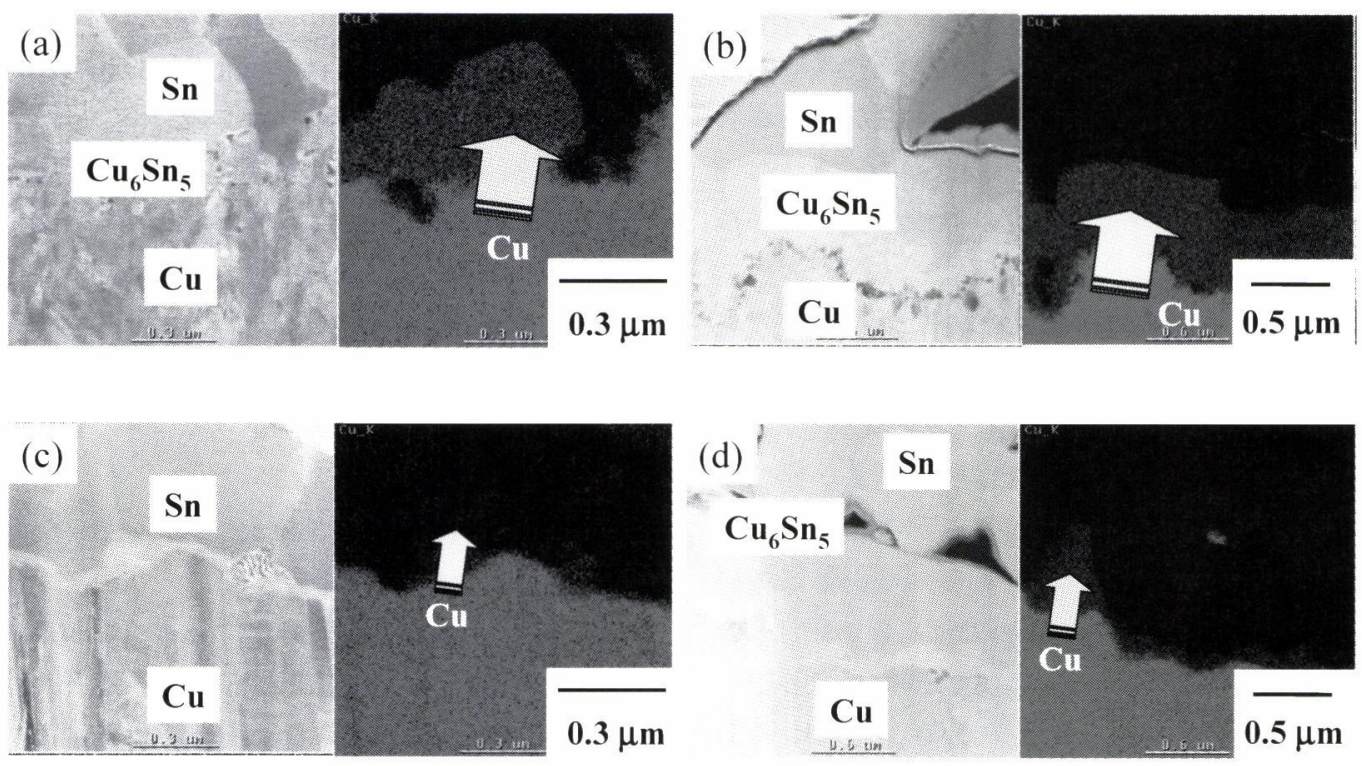

Fig. 7 Cross sectional TEM dark-field images and EDS mapping images of the interface between Sn deposited film and $\mathrm{Cu}$ foil. (a) gelatin, (b) gelatin 30 days, (c) $\mathrm{Cl}^{-}$, (d) $\mathrm{Cl}^{-} 30$ days

は，経時変化により増加していた。

それらの断面をEDSにより Cuの分布を調べた結果を Fig. 7 に示す。各条件の左側が暗視野像，右側が $\mathrm{Cu}$ の元素マッ
ピング像である。特にボイドが多く観察されたゼラチン添 加では, 作製後 30 月日では, 作製後 0 月日に比べて $\mathrm{Cu}$ Snめっき膜中に広く分布していることがわかる。一方で, 
$\mathrm{Cl}^{-}$添加では, わずかに $\mathrm{Cu}$ が $\mathrm{Sn}$ めっき膜中で検出されるも のの, その範囲はゼラチン添加に比べて小さいことがわか る。これらのことから発生したボイドは $\mathrm{Sn}$ 中への $\mathrm{Cu}$ の拡 散により形成された Kirkendall ボイドであると考えられる。

\section{4 ウィスカの発生メカニズムの考察}

これまでの実験結果より, 電解銅箔上の無電解 Snめっ きより発生するウィスカの発生メカニズムについて考察し た。作製したSnめっき膜と電解銅箔との界面近傍では, めっき膜作製後の時間経過とともに, Sn中への $\mathrm{Cn}$ の拡散 により電解銅䈃内にボイドが形成されており，このとき金 属間化合物 $\mathrm{Cu}_{6} \mathrm{Sn}_{5}$ の形成が確認できた。それらのことか ら，経時変化により $\mathrm{Sn}$ 中に拡散した $\mathrm{Cu}$ 原子により，金属 間化合物が形成されたと考えられる。

経時変化によるウィスカの発生数の変化 (Fig. 4) は，時間 とともに増加していた。特に, ゼラチン添加では, めっき 膜断面の TEM 観察により, 金属間化合物層の厚さが増加 していた 15 日目以降においてその傾向が顕著であることか ら，金属間化合物の形成とその増加がウィスカの発生数の 増加と相関していると考えられる。

$\mathrm{Sn}$ は正方晶系の結晶構造をもち $\mathrm{a}=\mathrm{b}=5.831 \AA \mathrm{A}, \mathrm{c}=3.182 \AA$, $\alpha=\beta=\gamma=90$ で, 一方金属間化合物 $\mathrm{Cu}_{6} \mathrm{Sn}_{5}$ は単斜晶系, $\mathrm{a}=11.033 \AA, \mathrm{b}=7.294 \AA, \mathrm{c}=9.83 \AA, \alpha=\gamma=90, \beta=98.82$ の結

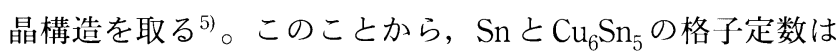
大きく異なることがわかる。そのため, $\mathrm{Cu}$ 原子の拡散によ り $\mathrm{Cu}_{6} \mathrm{Sn}_{5}$ が形成されると合金層による体積膨張が起こり, Snめっき膜に圧縮応力が発生し, それがウィスカ発生の駆 動力となると考えられる。Snめっき膜と基板との界面近傍 に形成される金属間化合物の形成亡ウィスカ発生との関係

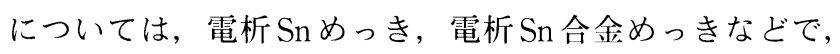
これまでにも多く検討されており，その相関性が指摘され ている2,3),6)。本研究で検討を行った無電解 $\mathrm{Sn}$ めっにおい ても, ウィスカの発生と金属間化合物の形成に相関性が認 められた。

ゼラチン添加と $\mathrm{Cl}^{-}$添加の電解銅箔との間のウィスカ発 生数の違いについても, 形成された金属間化合物 $\mathrm{Cu}_{6} \mathrm{Sn}_{5}$ 層 の厚さの違いがその原因と考えられる。ゼラチン添加と $\mathrm{Cl}^{-}$ 添加の電解銅箔において, 金属間化合物層の厚さが異なっ た原因は，(1)電解銅箔の結晶粒径が異なったこと, (2)電解 銅箔中の不純物による影響の違いが考えられる。(1)につい ては, 結晶粒径の小さいゼラチン添加では, $\mathrm{Cl}^{-}$添加より も粒界拡散の経路となる粒界が多く存在するため, Sn中へ の $\mathrm{Cu}$ の拡散速度が速くなったと考えられる。(2)について
は, EDSを用いて不純物元素の分布状態を調べたが，電解 銅箔の違いによる有意な差は見られなかった。そのため, 不純物元素の存在状態およびその関与については今後の検 討が必要である。

\section{4. 結 言}

・無電解Snめっき膜より発生するウィスカは, Snめっ き膜および電解銅箔の結晶粒径が小さい場合に多く発 生していた。

・ウィスカが生成していた場合には, Snめっき膜と電解 銅箔との界面近傍に $\mathrm{Cu}_{6} \mathrm{Sn}_{5}$ 金属間化合物が形成されて いた。

- 界面近傍に金属間化合物 $\mathrm{Cu}_{6} \mathrm{Sn}_{5}$ が形成された場合に は，電解銅箔内にボイドが形成されていた。

・電解銅箔の結晶粒径が異なることで, Snめっき膜中へ の $\mathrm{Cu}$ の拡散速度に違いが生じ, 形成される金属間化 合物層の厚さが変化した。

以上の結果から, 本研究で電解銅箔上に作製した無電解 Snめっき膜より発生するウィスカの発生原因は, 無電解 $\mathrm{Sn}$ めっき膜中への $\mathrm{Cu}$ 原子の拡散により金属間化合物 $\mathrm{Cu}_{6} \mathrm{Sn}_{5}$ が形成されたことに起因すると考えられる。

(2006.12.7-受理)

\section{文献}

1) 川中龍介, 藤原 裕, 辻 清貴, 伊藤貞則, 井原嵉行： “錫ウィスカ成長プロセスの解明と対策”, R\&D プランニン グ, 2006

2) K. S. Kim, C. H. Yu and J. M. Yang: "Tin Whisker Formation of Lead-Free Plated Leadframes”, Microelectronics Reliability, Vol. 46, pp. 1080-1086, 2006

3) K. Tsuji: "Study on the Mechanism of Sn Whisker Growth Part II Estimation of Excessive Energy \& Its Origin”, Journal of The Surface Finishing Society of Japan, Vol. 57, No. 6, pp. 451-458, 2006

4) 近藤和夫, 島田久美子, 田中善之助: “電解銅箔の結唱配 向性と成長”，エレクトロニクス実装学会誌，Vol. 6, No. 1, pp. 64-67, 2003

5) Joint Committee on Powder Diffraction Standards: "Powder Diffraction File”, 1972

6) I. Boguslavsky and P. Bush: "Recrystallization Principles Applied to Whisker Growth in Tin”, SUNY Buffalo, APEX conference, March 31, 2003, Anaheim, California 